\title{
The Use of Ribozyme Gene Therapy for the Inhibition of HIV Replication and its Pathogenic Sequelae
}

\author{
Justin E. Rigden, Julie A. Ely, Janet L. Macpherson, \\ Wayne L. Gerlach, Lun-Quan Sun, \\ and Geoff P. Symonds*
}

Johnson and Johnson Research Labs, GPO Box 3331, Sydney NSW 2001, Australia

\begin{abstract}
Human immunodeficiency virus (HIV) is a lentivirus, a separate genus of the Retroviridae which are RNA viruses that integrate as DNA copies into the genomes of host cells and replicate intracellularly through various RNA intermediates. Several of these RNA molecules can be targeted by ribozymes and a number of investigators, including our group, have demonstrated the ability of ribozymes to suppress HIV replication in cultured cells. It is argued that the use of this ribozyme gene therapy approach for the treatment of HIV infection may act as an adjunct to chemotherapeutic drugs and may affect not just viral suppression, but also immune restoration. This approach can be tested in Clinical Trials, several of which are currently under way.
\end{abstract}

\section{Introduction}

Acquired Immunodeficiency Syndrome (AIDS) and its associated disorders are caused by the human lentivirus, human immunodeficiency virus (HIV) (1-7). HIV type-1 (HIV-1) is the subtype of HIV which generally induces AIDS, HIV-2 being a rarer subtype found mainly in Africa (5).

The primary target cells for HIV infection in vivo are the $\mathrm{CD} 4^{+} \mathrm{T}$ lymphocytes, which are a major component of the immune system involved in humoral responses. AIDS is a descriptive term which reflects the progressive and irreversible destruction of the immune system; a relatively slow but inexorable decline in $\mathrm{CD}^{+} \mathrm{T}$ lymphocyte cell numbers being the most obvious manifestation. Historically, the loss of CD4 ${ }^{+} \mathrm{T}$ lymphocyte function over the course of ten years or so has been shown to severely compromise the immune system (1-7). Ultimately, complete immune failure concurrent with multi-organism opportunistic infection occurs, frequently associated with neurological symptoms and cancers such as Karposi's sarcoma and lymphomas (1-7). The course of the disease follows four recognised stages - initial infection, acute syndrome, clinical latency, and finally clinical disease (1-14). Viral replication is found at all of these stages, although with a degree of variation in terms of viral load (14-16). A host immune response is found with relatively high levels of antibodies to the HIV structural proteins env and p24 as well as HIV specific cytotoxic T lymphocytes (1-7). Again, historically, and in the absence of long-term data with the most recent therapeutics, there is an extremely high mortality rate of $90-100 \%$ over a period of approximately 10 years associated with the progression of AIDS.

\section{The Infectious Cycle of HIV}

HIV is a member of the lentivirus family of retroviruses. The HIV genome is about $9.8 \mathrm{~kb}$ in size and contains the same three replicative genes ( $\mathrm{gag}$, pol, env) found in the genomes of replication-competent oncogenic retroviruses. However, lentivirus genomes also contain additional regulatory (for HIV - tat, rev, tev, vpr, nef) and accessory (for HIV - vpu, vif) genes (see Figure 1; 17-19). This additional level of genomic complexity provides an intricate and refined level of control for viral replication and allows for viral expression and production of progeny virus for the duration of an infected cell's lifetime. HIV generally infects cells containing the CD4 receptor in combination with other co-receptors, such as the chemokine receptors CXCR-4 and CCR-5 (20-23). Following binding to the target cell receptors, there is fusion of the viral and target cell membranes and, through the process of uncoating, genomic RNA (in association with the viral proteins integrase, polymerase and reverse transcriptase) enters the host cell cytoplasm (17-19). The viral RNA is converted to a cDNA copy by the action of viral reverse transcriptase and polymerase proteins and this dsDNA copy is transported to the cell nucleus and is integrated into the host genome by the action of the viral integrase protein. This proviral DNA now behaves as a stable component of the host cell genome. It may remain dormant or become actively transcribed to genomic viral RNA and sub-genomic messages, to eventually yield mature virions which are released by budding (17-19). Productive infection of CD4+ $\mathrm{T}$ lymphocytes results in cell killing with a half-life of approximately two days (14-16). This infectious cycle is shown in diagrammatic form in Figure 2.

The Suitability of Ribozymes as Therapeutic Agents in the Treatment of Aids

AIDS is a disease with a viral etiology, but also has a marked immune component, as the virus slowly destroys the cells of the immune system leading to immunodeficiency (1-15). Therefore, an effective treatment can address two facets of the disease - reduction of viral burden and restoration of immune function. To date,

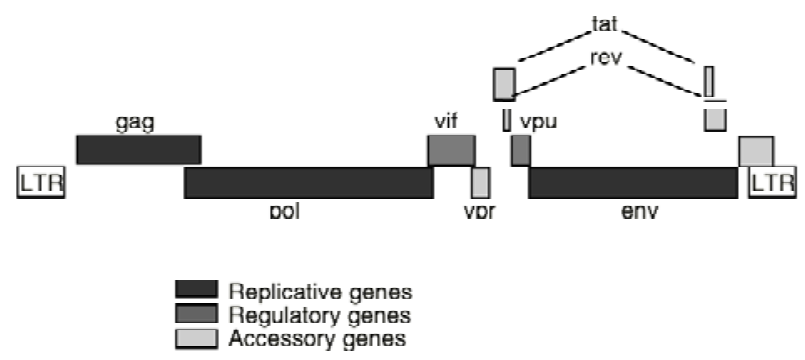

Figure 1. Genomic map of HIV-1. The location of viral open reading frames are shown as shaded boxes. 
therapies for the treatment of HIV infection have concentrated on the reduction of viral load using drugs that interfere with the replication of the virus. There is generally a modest affect increasing $T$-cell numbers. Triple combination therapy (TCT), generally involving two reverse transcriptase inhibitors and one protease inhibitor, is the most recent and relatively successful development in the management of HIV infection (24-26). TCT has shown great promise in terms of keeping the virus in check, often reducing levels of HIV in the blood to undetectable levels. However, now that TCT has been in general use for some time, side effects (gastrointestinal, lipodystrophy, hyperlipidemia, protease-related diabetes) are beginning to appear $(27,28)$ and strains of HIV are developing which are resistant to both reverse transcriptase and protease inhibitors $(28,29)$. It now seems appropriate to consider therapies which address more specifically the other potential aspect of disease management - immune restoration $(30,31)$. Such therapies, which include ribozyme gene therapy (89), may also impact on viral load, potentially without causing side effects.

Traditionally, therapies for infectious disease are pharmaceutical. Recent advances in molecular biology have made gene-based therapies feasible and while still relatively unproven, they represent one of the most exciting new areas in biomedical research. Five different genebased approaches (32) are being assessed for the treatment of infection with HIV-1: expression of intracellular antibodies to viral proteins $(33,34)$; antisense RNA expression to inhibit the reverse transcription, processing and translation of HIV-1 RNA $(35,36)$; expression of mutant HIV structural or regulatory genes such as rev M10 (3739) or tat (40-42), with dominant repressor activity; expression of RNA decoys such as RRE (43) and TAR (44) to inhibit HIV-1 transcription and processing; and ribozyme expression to catalytically cleave and thus inactivate HIV-1 RNAs (45-53). The infectious-cycle of HIV and the points at which these constructs can act are shown in Figure 2. This article will concentrate on recent developments in HIV-1 gene therapy using ribozymes.

Ribozymes have the potential to act at a variety of points in the HIV infectious cycle. These include:

i) the entry of genomic viral RNA into the target cell prior to reverse transcription,

ii) during transcription of structural and coding RNA molecules,

iii) prior to and during translation of mRNAs to viral proteins,

iv) prior to encapsidation of the genomic RNA during virion formation.

The cleavage of HIV RNA by ribozymes at these stages can result in a decrease in intracellular viral replication, potentially extending cell survival (52) and may result in a subsequent shift in the equilibrium of cellular destruction in vivo.

\section{Designing and Testing Ribozymes as Therapeutic Molecules}

Specificity of cleavage, potential for turnover and a lack of immunogenicity make ribozymes attractive as potential therapeutic agents. A number of factors need to be considered when designing and testing therapeutic ribozymes.
Choice of the RNA Target Site for Ribozyme Action

The selection of a target site is usually based on three criteria - i) biological significance of the target RNA, ii) the presence of a target triplet sequence recognised by the ribozyme and iii) accessibility of this sequence to ribozyme action $(47,52)$. The biological significance of a target RNA must be assessed for the target gene and it should be demonstrable that reduction or elimination of the target RNA has biological effect and will potentially be of therapeutic benefit (see below). The target site for hammerhead ribozyme cleavage within the target RNA is generally GUX, although in certain cases NUX may be used (where $N$ represents any nucleotide and $X$ represents $A$, $\mathrm{C}$ or $\mathrm{U})$. Once a suitable target RNA has been selected, ribozyme recognition triplets are searched for within regions that are likely to be accessible to ribozyme action. Accessibility can be assessed using RNA secondary structure analysis software on regions of RNA surrounding the potential cleavage site or by empirical experiments such as chemical modification mapping (54). In this way, it is possible to determine whether or not the target site is buried within an obvious thermodynamically stable secondary structure. These analyses give only an approximation to RNA secondary structure and accessibility in vivo and while, for example, they do not take into account RNA tertiary structures or potential RNA - protein interactions, they are still useful as a first stage for design of constructs to be tested further.

\section{In Vitro Cleavage}

Once potential target sites have been selected, the corresponding ribozyme sequences can be synthesized and tested in vitro for ability to cleave substrate RNA (5557). These in vitro cleavage reactions generally employ standard conditions ( $50 \mathrm{mM}$ Tris $\mathrm{HCl}, \mathrm{pH} 7.5,10 \mathrm{mM} \mathrm{MgCl}_{2}$, at $37^{\circ} \mathrm{C}$ ) and can be assessed for their ability to produce the expected size cleavage products when resolved using polyacrylamide electrophoresis gels (57).

Whilst a correlation between in vitro cleavage efficiency and in vivo ribozyme activity has been found (47), in vitro cleavage efficacy is not always consistent with in vivo activity, and in certain cases there is even an inverse relationship between these two activities (51). Therefore, although cleavage efficiency does yield information as to whether a particular ribozyme is chemically active in vitro, it does not necessarily indicate efficacy within cells.

\section{Efficacy in Tissue Culture}

In gene therapy approaches using ribozymes, it is necessary to incorporate the ribozyme sequence as a DNA copy into an expression vector for in vivo efficacy studies. A variety of vectors are available including relatively simple plasmid-based expression vectors in which the ribozyme is incorporated downstream of a mammalian promoter, as well as more complicated vectors based on the genomes of retroviruses or other viruses (57).

In order to improve transcription efficiency and increase the stability and sub-cellular targeting of ribozymes within cells, the ribozymes can be constructed as chimeras with other genes. To date, tRNA, U1 or U6 snRNA have all been used successfully as chimeric expression cassettes for ribozymes. Our experience is that the insertion of ribozyme sequences into the 3 '-untranslated region of the neomycin resistance gene within expression vectors leads to a high 


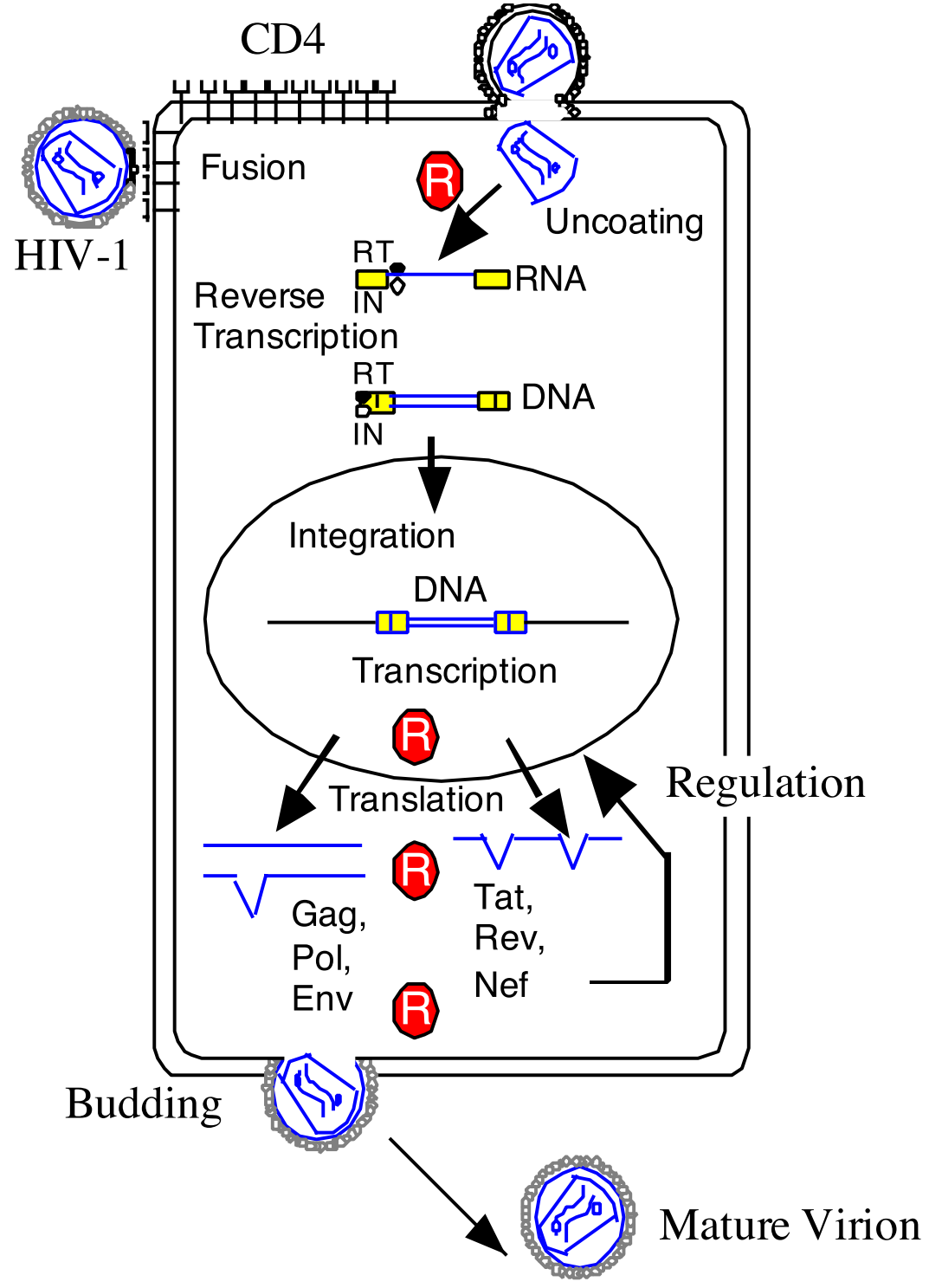

$\mathbb{B}=$ Point at which ribozymes can act
Figure 2. Infectious cycle of HIV-1 and potential sites of ribozyme action for the inhibition of HIV-1 replication. The virus enters the cell following the receptors on the cell surface, virall host membrane fusion and uncoating of the viral core. The viral core contains viral RNA as well as cove The viral core contains viral RNA as well as reverse transcriptase and integrase enzymes. The viral RNA is converted to DNA by the reverse transcriptase in the cytoplasm, which is transported into the nucleus where it becomes integrated into the host cell genome by the action of the integrase. Subsequent transcription/ translation of the provirus gives rise to mature virus particles which bud from the living cell. Potential sites of ribozyme action within the cell are indicated.

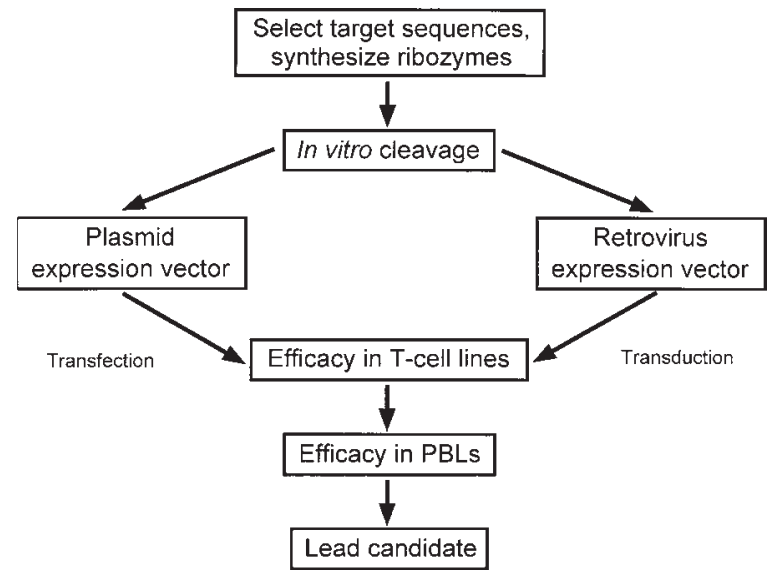

Figure 3. Strategy of construction and testing of anti-HIV ribozyme constructs. Ribozymes are selected to several candidate target sequences tested for efficacy in vitro and introduced into plasmid-based and retrovirusbased expression vectors. Efficacy is tested and compared in cultured cell lines and primary cells to determine the most efficacious, lead candidate ribozyme for further development. 


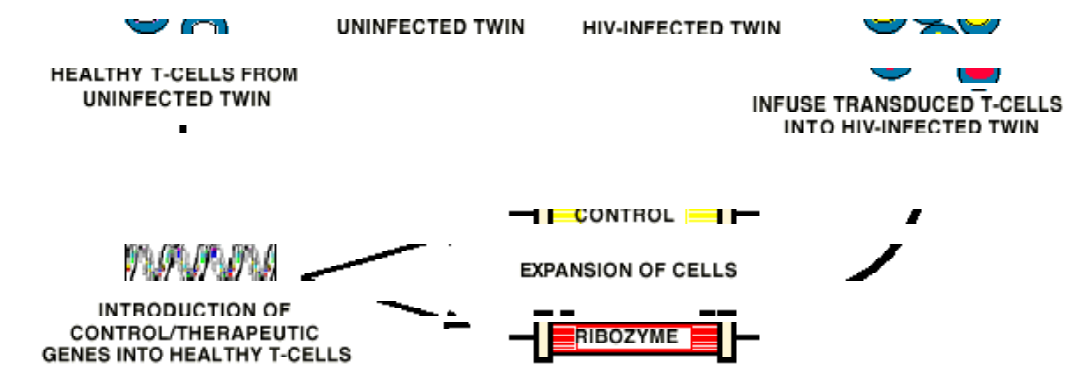

Figure 4. $\mathrm{CD}^{+}$cell based Clinical Trial. The trial involves pairs of identical twins who are discordant for HIV1 infection. Healthy T-cells from the HIV-negative individuals are transduced with ribozyme-producing and control retrovirus vectors, expanded ex vivo and introduced into the peripheral blood of the corresponding HIV-positive siblings. Cell survival of ribozyme-containing and control vector-containing cells within the HIVpositive individuals can be monitored by quantitative PCR designed to detect ribozyme and vector sequences.

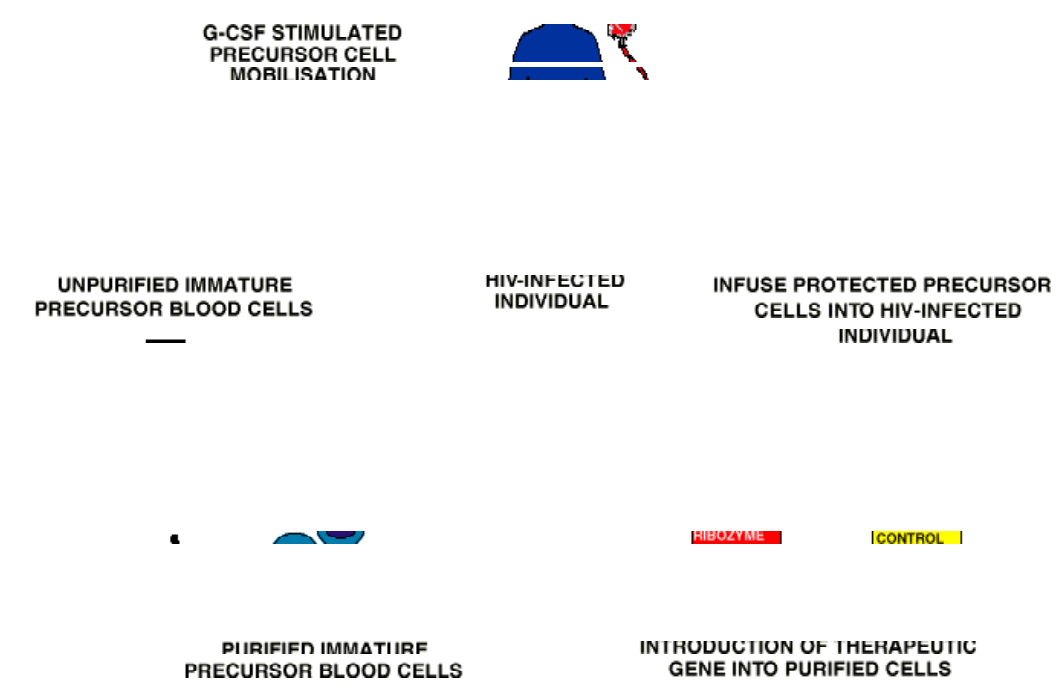

Figure 5. CD $34^{+}$cell based Clinical Trial. Pluripotent $C D 34^{+}$stem cells are harvested from HIV-positive individuals, further purified and transduced with ribozyme-containing and control retrovirus vectors before reintroduction into the bloodstream. The transduced CD $34^{+}$cells engraft into the bone marrow where they begin to differentiate into the component cells of the hematopoeitic system. Survival of ribozyme-containing and control vector-containing progeny cells can be determined by fractionation of blood samples and tissue biopsies into various cell types using fluorescence activated cell sorting followed by quantitative PCR to detect ribozyme and vector sequences. 
level expression of the neo/ribozyme chimeric RNA transcript. In addition, this approach has the added benefit of introducing a selectable marker for ribozyme RNA expression $(47,52,57)$, allowing for the selection of populations of cultured cells which are known to exhibit high levels of ribozyme expression for in vivo studies.

Ribozymes have been demonstrated to successfully modulate the expression of a number of different genes in various tissue culture systems. Cleavage of substrate RNA by ribozyme action within the cell is followed by a rapid degradation of cleavage products, and therefore direct detection of the RNA cleavage products is extremely difficult. However, a number of markers for ribozyme activity have been used to demonstrate the efficacy of ribozymes in the control of gene expression. Such markers include the modulation of expression of encoded genes such as enzymes and changes in structural and cytokine gene expression, as well as inhibition of viral replication (5860).

The inhibition of HIV replication in cultured cells has been used to demonstrate ribozyme efficacy by our own and a number of other groups (46, 47, 51-53, 61-67). Following introduction of the ribozyme construct into cell lines or primary cells, ribozyme-mediated inhibition of HIV replication can be assayed by ELISA monitoring of viral protein production. The ribozyme design, construction and testing procedure used by our group for such studies is outlined in Figure 3.

\section{A Model System for Ribozyme-Mediated Retroviral Inhibition}

Initially, our work focussed on the use of a Moloney murine leukemia virus (MoMLV) model system to test the utility of ribozymes as anti-retroviral agents. We demonstrated that the $\psi$ packaging site, which is essential for packaging of viral genomic RNA, can be effectively targeted to inhibit MoMLV replication (47). The efficacy of substrate cleavage in vitro by $\psi$ packaging site-targeted ribozymes correlated well with inhibition of MoMLV replication in vivo (47). An extension of this work demonstrated a high level of ribozyme specificity when targeting the $\psi$ packaging site. Ribozymes could be designed to specifically target the MoMLV $\psi$ packaging site whilst not affecting the MoMSV variant sequence within the retroviral vector expressing the ribozyme itself, despite minimal variation between the two $\psi$ packaging site sequences. Recombinant virus could be produced efficiently from ribozyme containing provirus without an apparent inhibition of vector titre, and cultured cells transduced with this ribozyme-containing recombinant virus were shown to inhibit target MoMLV replication (68).

\section{Design and Testing of Anti-HIV Ribozymes}

HIV shows considerable sequence variation between isolates and is known to mutate rapidly in response to treatment with anti-viral agents. Therefore, for ribozymes to be clinically effective against multiple isolates, these ribozyme target sites must be important to viral replication an aspect which should be mirrored by the sites being conserved in sequence. We decided to choose two well conserved sites as targets in our studies, one in the $\psi$ region (47) and another in the 5 ' region of the first coding exon of tat (52). It has been demonstrated that these two sites are highly conserved in HIV clades and ribozymes targeted to these sites (particularly the latter) were subsequently shown to inhibit a wide range of HIV-1 isolates $(47,52,61,69)$.

A number of studies employing ribozymes targeting different sites within the genome of HIV-1 have shown that they can effectively inhibit HIV replication in cultured cells. Sarver and colleagues (70) using a gag targeting ribozyme showed inhibition of HIV replication. Another group (67) introduced ribozymes targeting the HIV-1 5'-leader sequence into a stable MT4 cell line, by MoMLV based retroviral vector transfer, and demonstrated an acquired resistance to HIV-1 infection. Other investigators have used ribozyme constructs engineered to specifically cleave within the sequence of the tat gene of HIV-1 (66). Cells transduced with these ribozymes showed a delay in the appearance of measurable HIV. In addition, a hairpin ribozyme construct expressed from a tRNA ${ }^{\mathrm{Val}}$ transcriptional cassette within various expression vectors has been shown to confer resistance to several HIV-1 isolates (62-64, 71-73).

In our own studies we have used constructs in which the ribozyme was cloned into the 3'-untranslated region of the neo gene and driven by the SV40 promoter in a plasmidbased expression vector or inserted into a MoMLV-based retroviral vector. Ribozymes which targeted either the HIV tat gene $(52,61)$ or the $\psi$ packaging site of HIV-1 (47), protected T-lymphocyte cell lines from HIV-1 infection in terms of delay of HIV-1 replication and absolute virus levels (determined by syncytia formation and p24 ELISA antigen assay). Replication of the virus was inhibited by $70-95 \%$ for the laboratory adapted HIV-1 isolates SF2 and IIIB and by 2 -4 logs for primary clinical isolates $(47,52,61)$. A second T lymphocyte cell culture system (CEM T4 cell line) was also used (69). CEM T4 cells were transduced with amphotropic retrovirus containing the same neo/ribozyme expression cassettes and conditions were established to allow a mixed pool of transduced cells to be challenged with HIV-1 and then assayed. As for the initial Sup T1 assay, the anti-HIV efficacy of constructs was determined by analysing p24 antigen production in comparison with cells transduced with the vector alone (69).

In both systems, the most effective ribozyme construct, termed Rz2, was one directed to a site in the first coding exon of tat $(47,52,61,69)$. When cloned into the MoMLV based vector LNL6, this construct was designated RRz2 and formed the basis for our later work. This construct elicited a marked anti-viral effect, reducing p24 antigen levels by $70-90 \%$ when compared to LNL6 vector controls in a series of experiments. In addition, the RRz2 construct was demonstrated to offer protection against a range of clinical HIV-1 isolates, including virus taken from patients known to have failed treatment with anti-viral drugs (69).

The results obtained in the $T$ lymphocyte cell line studies were confirmed with more clinically relevant assays using both total and $\mathrm{CD}^{+}$enriched non-HIV infected peripheral blood lymphocytes (PBLs). PBLs were obtained from random normal blood donor packs by Ficoll/Hypaque separation and $\mathrm{CD} 4^{+}$enriched using $\mathrm{CD}^{+}$MicroCELLector TM flasks (Applied Immune Systems/RPR Gencell) to deplete $\mathrm{CD} 8^{+} \mathrm{T}$ lymphocytes. Both total and CD4 ${ }^{+}$enriched PBLs were then transduced with LNL6 (the MoMLV-based vector used in ribozyme construction) and RRz2 retrovirus. The cells were selected with an appropriate donor-specific dose of G418 and challenged with HIV-1 as in the previous studies using cell lines. RRz2, the retroviral construct 
shown to be effective in the pooled T lymphocyte assays was also effective in this assay giving inhibition of $70-90 \%$ when compared to the LNL6 control; other ribozymecontaining constructs were less effective in this assay. A recombinant retrovirus engineered to contain polyTAR and shown by others to be effective in T cell lines (44) was used as a positive control in these studies. In the PBL assay, this polyTAR retrovirus was found to be somewhat less efficient than RRz2 (52).

The RRz2 and LNL6 vectors were also used to transduce PBLs from HIV-1 infected patients. Paired analysis showed that cell viability in the ribozymetransduced HIV-1 infected PBLs was significantly higher than that in the vector-transduced cells. This difference in viability between RRz2 and LNL6 transduced cells was not observed in PBLs from non-infected donors (69). This observation was the first evidence that a ribozyme can impact on the survival of HIV-1 infected patient derived PBLs in cell culture (69) and implies that the ribozymeexpressing cells may have a growth viability advantage over non-transduced cells within HIV-1-infected patients. This is presently being tested in Clinical Trials by our group (see below).

We have conducted further studies to validate the specificity of ribozyme action against HIV-1. To address this issue, another ribozyme, Rz1, which targets the 5 splicing region of the tat gene was designed to cleave GUC $\mathrm{N}$ in which $\mathrm{N}$ is a G in HIV-1 IIIB and A in HIV-1 SF2. The data from both in vitro and in vivo studies with Rz1 showed that this ribozyme could protect cells only from those HIV isolates whose genomic sequence was cleavable in vitro. This demonstrated the importance of the first base pair distal to the NUX within helix I of the hammerhead structure for both in vitro and in vivo ribozyme activities. (61). This is in contrast to Rz2, which inhibits both strains of HIV-1, due to sequence conservation at the Rz2 target site $(52,61$, 69).

To address issues of the impact of ribozyme expression on the viral population in terms of virus sequence integrity and, specifically the appearance of ribozyme-resistant sequence mutations, a multiple-passage assay was developed to analyse HIV-1 sequence variation and viral replication dynamics in ribozyme-expressing cells. These studies demonstrated that Rz2 ribozyme expression in transduced human $T$ cells did not provide selective conditions for the emergence of resistance mutations over five sequential viral passages, and resulted in the rapid disappearance of certain quasi-species of HIV-1 (69). The rapid disappearance of this "less fit" quasi-species argues for a selective pressure. These data further argue for the potential clinical use of the Rz2 anti-HIV ribozyme.

\section{Considerations for Clinical Studies with an Anti-HIV Ribozyme}

The major obstacles that must be addressed in gene therapy applications are the efficient delivery of therapeutic sequences into relevant cell populations and subsequent therapeutic gene expression within patients. Retroviral vectors are the preferred delivery system for most studies at the present time as they are relatively efficient, have a good track record for safety, integrate into host genomes in a stable fashion and have often shown persistent levels of expression $(74,75)$. Presently, over 300 gene therapy clinical trials have been approved worldwide, a large majority of which rely on retroviral vectors to carry marker or therapeutic genes into target cell populations $(76,77)$. Most of these trials (including our own) utilise vectors derived from MoMLV. However, retroviral vectors such as these do have some limitations. The percentage of cells infected by retroviruses are sometimes limited by culture conditions and, more importantly, MoMLV-based vectors require cell division for stable integration. Recently, advances have been made in the use of gibbon ape leukemia virus (GaLV) (78) or vesicular somatititis virus (VSV) G-glycoprotein pseudo-typed retroviral vectors (79). These vectors appear to be more efficient at infecting a larger number of human cell types than standard MoMLVbased amphotropic virus, and have the potential for higher transduction efficiencies when compared to MoMLV-based amphotropic retroviruses (80). However, lowering the viral harvest temperature to $32^{\circ} \mathrm{C}$ and using concentrated virus, both of which increase the effective multiplicity of infection, can mitigate this apparent advantage by acting to increase standard amphotropic viral transduction efficiency (81).

Adeno-associated virus (AAV), is another viral system which is being developed as a gene delivery vector and has been shown to be capable of stable and efficient insertion of anti-HIV-1 genes into hematopoietic cells (82). Chatterjee and colleagues (83) have reported the use of AAV vectors to transduce an HIV-1 antisense construct into human $T$ cells, resulting in a significant reduction of virus levels following challenge of transduced cells with purified HIV-1. AAV-based vectors have several potential advantages over retrovirus-based vectors that are relevant for HIV-1 gene therapy (84). They appear to have no potential for homologous recombination and give high transduction efficiency in hematopoietic cells, including progenitor cells. In addition, AAV is non-pathogenic, replication-incompetent and is able to transduce nondividing cells. However, for clinical application there are still major problems with the use of AAV. A limit of approximately $4.7 \mathrm{~kb}$ exists for the insertion of exogenous sequences, a potential for adenovirus contamination exists and it is possible that integrated sequences will excise or at least be unstable. Indeed, the expression of a truncated rat nerve growth factor receptor reporter gene delivered to hematopoietic cells using an AAV vector was observed to decline by $50-90 \%$ over a two month period (85).

Another approach for the introduction of therapeutic genes being investigated is the use of vectors based on HIV-1 (86). HIV-1 based vectors are yet to be used in any clinical studies, but they may have a number of advantages over existing vectors. Such vectors may have the ability to infect non-dividing cells and a possibility exists for tat inducible (and therefore HIV-1 infection-specific) expression $(76,87)$.

A number of groups have demonstrated that ribozymes cleave HIV-1 and suppress its replication in tissue culture systems. However, the more important questions of whether ribozymes can affect the disease course of AIDS and impact on the two surrogate markers of advancing disease - viral load and CD4 ${ }^{+} \mathrm{T}$ cell counts - are yet to be addressed. Several clinical trials aimed at answering these questions are being conducted by a number of groups, including our own.

Regarding target cells for gene therapy using anti-HIV ribozymes, hematopoietic CD $34^{+}$stem cells appear to be 
the ideal choice. However, the ability of such ex vivo manipulated precursor cells to reconstitute all hematopoietic lineages is still not well defined. The establishment of optimal conditions for ex vivo manipulation of $\mathrm{CD}_{3} 4^{+}$cells in terms of subsequent pluripotential reconstitution and improvement in vector systems to stabilise transduced gene expression in stem cell progeny still represent major obstacles. A simpler approach to treating HIV-infected patients might be the infusion of transduced CD4 ${ }^{+}$PBLs. Observations of how the HIV-1 population behaves in the body suggest that the battle between the immune system and the virus is matched and that any approach which weakens virus replication and gives the immune system a slight but maintained advantage might be sufficient to elicit a significant effect $(15,16)$. Therefore, if ribozyme constructs can protect CD $4^{+} \mathrm{T}$ cells from HIV-1 infection and its sequelae in patients, the decline in the numbers of $\mathrm{CD}^{+} \mathrm{T}$ cells could be halted or even reversed resulting in potential clinical benefit to these individuals. However, there are other concerns regarding such PBL-based therapy, such as i) the potential effect on susceptibility of the T cells to HIV infection due to ex vivo activation, ii) the role played by non-T cell populations such as the macrophage and iii) possible downregulation of therapeutic gene expression from the proviral LTR in the absence of T cell activation (88). Studies on these cell types should provide the foundations for the future gene therapy approaches that may be used to treat HIV infection.

\section{Current Phase I Clinical Trials of an Anti-HIV Ribozyme}

We have initiated two independent Phase I Clinical Trials to test safety, the ability to detect ribozyme-containing cells in the bloodstream and the hypothesis that ribozymes can protect CD4 ${ }^{+}$T-lymphocytes from rapid HIV-1 mediated destruction within an infected individual. Both trials utilise LNL6 vector (a MoMLV-based expression vector) and recombinant LNL6 containing Rz2 (RRz2), and each trial uses a separate target cell population - CD4 ${ }^{+}$PBLs and $\mathrm{CD}_{34}{ }^{+}$stem cells - for the reasons discussed in the previous section. The first trial involves identical twins, discordant for infection with HIV (Figure 4). Healthy CD4 ${ }^{+}$ lymphocytes from the uninfected twin are transduced with a retroviral vector containing the ribozyme gene. These transduced cells are cultured and expanded ex vivo (81) before transfusion into the bloodstream of the corresponding HIV-positive twin.

The second Clinical Trial involves the removal, transduction and transfusion of $\mathrm{CD}_{3} 4^{+}$stem cells within HIV-positive individuals (Figure 5). The rationale being that these transduced stem cells will differentiate and give rise to a variety of lineages which express the ribozyme.

In each of the trials, separate populations of cells are transduced with the retrovirus vector containing the ribozyme and the vector alone as a control, and equal numbers of these two transduced cell types are then introduced into the recipient patients (Figures 4 and 5). This has allowed us to monitor the survival of ribozyme expressing $\mathrm{CD}^{+}$Iymphocytes relative to a similar population of transduced CD4+ lymphocytes which have been processed in an identical fashion but do not contain the ribozyme sequence. Cell survival is being monitored by detecting ribozyme and control vector DNA sequences in peripheral blood using quantitative PCR procedures (81).

\section{Concluding Remarks}

Infection with HIV represents an enormous challenge for any therapy due to the complexity of HIV pathogenesis, the multiple levels of control of proviral expression and the ability of the virus to rapidly mutate. Ribozymes are only one of several possible gene therapy-based anti-HIV approaches. Studies to date, indicate that ribozymes can be effective in suppressing HIV-1 replication in tissue culture systems and it can be expected that continued improvement in the design of these and other anti-HIV-1 constructs will increase the potential for gene therapy approaches to AIDS. At the same time, improvements in delivery systems and the use of combinations of different strategies such as multi-faceted gene therapies, new drugs and immune modulators should result in more efficient inhibition of HIV-1 which can in turn lead to improvements in performance in the clinic. The ability of ribozymes to impact on AIDS are being tested clinically, initially in Phase I safety studies, each of which, due to the nature of their design, has the capacity to provide some evidence as to efficacy in terms of preferential cell survival. We await the outcome of these trials.

\section{Acknowledgements}

Some of the work described herein was conducted in conjunction with Gene Shears Pty Ltd, Australia.

\section{Further Reading}

Rossi, J.J. and Couture, L.A. 1999. Intracellular Ribozyme Applications: Principles and Protocols. Horizon Scientific Press, Wymondham, UK.

\section{References}

1. Weiss, R.A. 1993. How does HIV cause AIDS? Science. 260: 12731279.

2. Fauci, A.S. 1993. Multifactorial nature of HIV disease: implications for therapy. Science. 262: 1011-1018.

3. McCune, J.M. 1995. Viral latency in HIV disease. Cell. 82: 183-188.

4. Baltimore, D. 1995. The enigma of HIV infection. Cell. 82: 175-176.

5. Johnston, M.I., and Holt, D.F. 1993. Present status and prospects for HIV therapies. Science. 260: 1286-1293.

6. Barré-Sinoussi, F. 1996. HIV as the cause of AIDS. The Lancet 348: 31-35.

7. Coffin J. 1992. Structure and classification of retroviruses. In: The Retroviridae. J. Levy, ed. Plenum, New York. p. 19-50.

8. Ho, D.D., Moudgil, T., and Alam, M. 1989. Quantitation of human immunodeficiency virus type 1 in the blood of infected persons. N. Engl. J. Med. 321: 1621-1625.

9. Pantaleo, G., Graziosi, C., Butini, L., Pizzo, P.A., Schnittman, S.M., Kolter, D.P., and Fauci, A.S. 1989. Lymphoid organs function as major reservoirs for human immunodeficiency virus. Proc. Natl. Acad. Sci. USA. 88: 9838-9842.

10. Clark, S.J., Saag, M.S., Decker, W.D., Campbell-Hill, S., Roberson, J.L., Veldkamp, P.J., Kappes, J.C., Hahn, B.H., and Shaw, G.M. 1991. High titers of cytopathic virus in plasma of patients with symptomatic primary HIV-1 infection. N. Engl. J. Med. 324: 954-960.

11. Daar, E.S., Moudgil, T., Meyer, R.D., and Ho, D.D. 1991. Transient high levels of viremia in patients with primary human immunodeficiency virus type 1 infection. N. Engl. J. Med. 324: 961-964.

12. Saag, M.S., Crain, M.J., Decker, W.D., Campbell-Hill, S., Robinson, S., Brown, W.E., Leuther, M., Whiteley, R.J., Hahn, B.H., and Shaw, G.M. 1991. High-level viremia in adult and children infected with human immunodeficiency virus: relation to disease stage and CD4+ lymphocyte levels. J. Infect. Dis. 164: 72-80.

13. Chun ,T.W., Carruth, L., Finzi, D., Shen, X., DiGiuseppe, J.A., Taylor, H., Hermankova, M., Chadwick, K., Margolick, J., Quinn, T.C., Kuo, Y.-H., Brookmeyer, R., Zeiger, M.A., Barditch-Crovo, P., and Siliciano, R.F. 1997. Quantification of latent tissue reservoirs and total body viral load in HIV-1 infection. Nature. 387: 183-8.

14. Finzi D and Siliciano, R.F. 1998. Viral dynamics in HIV-1 infection. Cell. 93: 665-71. 
15. Wei, X., Ghosh, S.K., Taylor, M.E., Johnson, V.A., Emini, E.A., Deutsch, P., Lifson, J.D., Bonhoeffer, S., Nowak, M.A., Hahn, B.H., Saag, M.S. and Shaw, G.M. 1995. Viral dynamics in human immunodeficiency virus type 1 infection. Nature. 373: 117-122.

16. Ho, D.D., Neumann, A.U., Perelson, A.S., Chen, W., Leonard, J.M. and Markowitz, M. 1995. Rapid turnover of plasma virions and CD4 lymphocytes in HIV-1 infection. Nature. 373: 123-126.

17. Trono, D. 1995. HIV accessory proteins: Leading roles for the supporting cast. Cell. 82: 189-192.

18. Varmus, H. 1988. Regulation of HIV and HTLV gene expression. Genes Dev. 2: 1055-1062.

19. Emerman, M., and Malim, M.H. 1998. HIV-1 regulatory/accessory genes: keys to unraveling viral and host cell biology. Science. 280 1880-4.

20. Berger, E.A. 1997. HIV entry and tropism: the chemokine receptor connection. AIDS. 11: s3-s16.

21. Levy, J.A. 1996. Infection by human immunodeficiency virus - CD4 is not enough. N. Engl. J. Med. 335: 1528-1530.

22. Wyatt R., and Sodroski, J. 1998. The HIV-1 envelope glycoproteins: fusogens, antigens, and immunogens. Science. 280: 1884-8.

23. Dittmar M.T., McKnight, A., Simmons, G., Clapham, P.R., Weiss, R.A., and Simmonds, P. 1997. HIV-1 tropism and co-receptor use. Nature. 385: 495-6.

24. Corey, L., and Holmes, K.K. 1996. Therapy for human immunodeficiency virus infection - what have we learned? New Eng. J. Med. 335: 1142-1143.

25. Cooper, D.A., and Merigan, T.C. 1996. Clinical treatment. AIDS. 10 Supp. A, S133-S134.

26. Autran B., Carcelain G., Li, T.S., Blanc, C., Mathez, D., Tubiana, R. Katlama, C., Debré, P., and Leibowitch, J. 1997. Positive effects of combined antiretroviral therapy on CD4+ T cell homeostasis and function in advanced HIV disease. Science. 277: 112-6.

27. Carr, A., Samaras, K., Burton, S., Law, M., Freund, J., Chisholm, D.J., and Cooper, D.A. 1998. A syndrome of peripheral lipodystrophy, hyperlipidaemia and insulin resistance in patients receiving HIV protease inhibitors. AIDS. 12: F51-F58.

28. Flexner, C. 1998. HIV-Protease Inhibitors. Drug Therapy. 338: 1281 1292.

29. Perrin, L., and Telenti, A. 1998. HIV treatment failure: Testing for HIV resistance in clinical practice. Science. 280: 1871-3.

30. Pantaleo, G. 1997. How immune-based interventions can change HIV therapy. Nature Med. 3: 483-6.

31. Emery, S., and Lane, H.C. 1997. Immune reconstitution in HIV infection. Curr. Opin. Immunol. 9: 568-72.

32. Bridges, S.H., and Sarver, N. 1995. Gene therapy and immune restoration for HIV disease. Lancet. 345: 427-432.

33. Maciejewski, J.P., Weichold, F.F., Young, N.S., Cara, A., Zella, D. Retiz Jr, M.S., and Gallo, R.C. 1995. Intracellular expression of antibody fragments directed against HIV reverse transcriptase prevents HIV infection in vitro. Nature Med. 1: 667-673.

34. Shaheen, F., Duan, L., Zhu, M., Bagasra, O., and Pomerantz, R.J. 1996. Targeting human immunodeficiency virus type 1 reverse transcriptase by intracellular expression of single-chain variable fragments to inhibit early stages of the viral life cycle. J. Virol. 70: 3392-3400.

35. Smythe, J.A., and Symonds, G. 1995. Gene therapeutic agents: the use of ribozymes, antisense and RNA decoys for HIV-1 infection. Inflamm. Res. 44: 11-15.

36. Cohen, J.S.. Oligodeoxynucleotides: Antisense Inhibitors of Gene Expression. CRC Press, Boca Raton, FL.

37. Woffendin, C., Yang, Z-Y., Udaykumar, Xu, L., Yang, N-S., Sheehy, M.J., and Nabel, G.J. 1994. Nonviral and viral delivery of a human immunodeficiency virus protective gene into primary human $T$ cells. Proc. Natl. Acad. Sci. USA. 91: 11581-11585.

38. Escaich, S., Kalfoglou, C., Plavec, I., Kaushal, S., Mosca, J.D., and Böhnlein, E. 1995. RevM10-mediated inhibition of HIV-1 replication in chronically infected T cells. Human Gene Ther. 6: 625-634.

39. Woffendin, C., Ranga, U., Yang, Z.-Y, Xu, L, and Nabel, G.J. 1996. Expression of a protective gene prolongs survival of T-cells in human immunodeficiency virus-infected patients. Proc. Natl. Acad. Sci. USA 93: 2889-94.

40. Aguilar-Cordova, E., Chinen, J., Donehower, L.A., Harper, J.W., Rice, A.P., Butel, J.S., and Belmont, J.W. 1995. Inhibition of HIV-1 by a double transdominant fusion gene. Gene Therapy. 2: 181-186.

41. Caputo, A., Grossi, M.P., Bozzini, R., Rossi, C., Betti, M., Marconi, P.C., Barbanti-Brodano, G., and Balboni, P.G. 1996. Inhibition of HIV1 replication and reactiviation from latency by tat transdominan negative mutants in the cysteine rich region. Gene Therapy. 3: 235245
42. Lisziewicz, J., Sun, D., Lisziewicz, A., and Gallo, R.C. 1995. Antitat gene therapy: a candidate for late-stage AIDS patients. Gene Therapy. 2: 218-222.

43. Lee, S.W., Gallardo, H.F., Gilboa, E., and Smith, C. 1994. Inhibition of human immunodeficiency virus type 1 in human $T$ cells by a poten Rev response element decoy consisting of the 13 nucleotide minimal Rev binding domain. J. Virol. 68: 8254-8264.

44. Lisziewicz, J., Sun, D., Smythe, J., Lusso, P., Lori, F., Louie, A., Markham, P., Rossi, J., Reitz, M., and Gallo, R.C. 1993. Inhibition of human immunodeficiency virus type 1 replication by regulated expression of a polymeric Tat activation response RNA decoy as a strategy for gene therapy for AIDS. Proc. Natl. Acad. Sci. USA. 90: 8000-8004.

45. Kuwabara, T., Amontov, S.V., Warashina, M., Ohkawa, J., and Taira, K. 1996. Characterization of several kinds of dimer minizyme: simultaneous cleavage at two sites in HIV- 1 tat mRNA by dimer minizymes. Nucleic Acids Res. 24: 2302-2310.

46. Rossi, J.J., Elkins, D., Zaia, J.A., and Sullivan, S. 1992. Ribozymes as anti-HIV-1 therapeutic agents: Principles, applications, and problems. AIDS Res. Human Retroviruses. 8: 183-189.

47. Sun, L-Q, Warrilow, D., Wang, L., Witherington, C., Macpherson, J., and Symonds, G. 1994. Ribozyme-mediated suppression of Moloney murine leukemia virus and human immunodeficiency virus type 1 replication in permissive cell lines. Proc. Natl. Acad. Sci. USA. 91: 9715-9719.

48. Heidenreich, O., and Eckstein, F. 1992. Hammerhead ribozymemediated cleavage of the long terminal repeat RNA of human immunodeficiency virus type 1. J. Biol. Chem. 267: 1904-1909.

49. Sioud, M., and Drlica, K. 1991. Prevention of human immunodeficiency virus type 1 integrase expression in Escherichia coli by a ribozyme. Proc. Natl. Acad. Sci. USA. 88: 7303-7307.

50. Rossi, J.J., Cantin, E.M., Sarver, N., and Chang, P.F. 1991. The potential use of catalytic RNAs in therapy of HIV infection and other diseases. Pharmac. Ther. 50: 245-254.

51. Crisell, P., Thompson, S., and James, W. 1993. Inhibition of HIV-1 replication by ribozymes that show poor activity in vitro. Nucleic Acids Res. 21: 5251-5255.

52. Sun , L,-Q., Pyati, J., Smythe, J., Wang, L., Macpherson, J., Gerlach, W., and Symonds, G. 1995. Resistance to human immunodeficiency virus type 1 infection conferred by transduction of human peripheral blood lymphocytes with ribozyme, antisense or polymeric transactivation response element constructs. Proc. Natl. Acad. Sci. USA. 92: 7272-7276.

53. Homann, M., Tzortzakaki, S., Rittner, K., Sczakiel, G., and Tabler, M. 1993. Incorporation of the catalytic domain of a hammerhead ribozyme into antisense RNA enhances its inhibitory effect on the replication of human immunodeficiency virus type 1. Nucl. Acids Res. 21: 28092814.

54. Campbell, T.B., McDonald, C.K., and Hagen, M. 1997. The effect of structure in a long target RNA on ribozyme cleavage efficiency. Nucl. Acids Res. 25: 4985-4993.

55. Hampel, A., Nesbitt, S., Tritz, R., and Altschuler, M. 1993. The hairpin ribozyme. Meth. Enzymol. 5: 37-42.

56. Haseloff, J., and Gerlach, W.L. 1988. Simple enzymes with new and highly specific endoribonuclease activity. Nature. 334: 585-591.

57. Sun, L.-Q., Gerlach, W.L., and Symonds, G. 1998. The design production and validation of an anti-HIV type 1 ribozyme. In: Methods in Molecular Medicine, Vol. 11: Therapeutic Applications of Ribozymes. K.J. Scanlon, ed. Humana Press Inc., Totowa, N.J.

58. James, W., and Al-Shamkhani, A. 1995. RNA enzymes as tools for gene ablation. Curr. Opin. Biotechnol. 6: 44-49.

59. Usman, N., and Stinchcomb, D.T. 1996. Design, synthesis, and function of therapeutic hammerhead ribozymes. In: Catalytic RNA. F. Eckstein, and D.M.J. Lilley, eds. Springer, Berlin. p. 243-264.

60. Cohen, M. 1990. The in vivo application of ribozymes. Trends Biotechnol. 8: 174-179.

61. Sun, L.-Q., Wang, L., Gerlach, W.L., and Symonds, G. 1995. Target sequence-specific inhibition of HIV-1 replication by ribozymes directed to tat RNA. Nucl. Acid Res. 23: 2909-2913.

62. Yu, M., Ojwang, J., Yamada, O., Hampel, A., Rapapport, J., Looney, D., and Wong-Staal, F. 1993. A hairpin ribozyme inhibits expression of diverse strains of human immunodeficiency virus type 1. Proc. Natl. Acad. Sci. USA. 90: 6340-6344.

63. Ojwang, J.O., Hampel, A., Looney, D.J., Wong-Staal, F., and Rappaport, J. 1992. Inhibition of human immunodeficiency virus type 1 expression by a hairpin ribozyme. Proc. Natl. Acad. Sci. USA. 89: 10802-10806.

64. Yamada, O., Kraus, G., Leavitt, M.C., Yu, M., and Wong-Staal, F. 1994. Activity and cleavage site specificity of an anti-HIV-1 hairpin 
ribozyme in human T cells. Virol. 205: 121-26.

65. Dropulic, B., Lin, N.H., Martin, M.A., and Jeang, K-T. 1992. Functiona characterization of a U5 ribozyme: intracellular suppression of human immunodeficiency virus type 1 expression. J. Virol. 66: 1432-1441.

66. Lo, K.M.S., Biasolo, M.A., Dehni, G., Palú, G., and Haseltine, W.A. 1992. Inhibition of replication of HIV-1 by retroviral vectors expressing tat-antisense and anti-tat ribozyme RNA. Virol. 190: 176-183.

67. Weerasinghe M., Liem, S.E., Asad, S., Read, S.E., and Joshi, S. 1991. Resistance to human immunodeficiency virus type 1 (HIV-1) infection in human CD4+ lymphocyte-derived cell lines conferred by using retroviral vectors expressing an HIV-1 RNA-specific ribozyme. J. Virol. 65: 5531-5534.

68. Lowenstein, P., and Symonds, G. 1997. Inhibition of Moloney murine leukaemia virus by a retroviral vector, LNL6, carrying ribozymes targeted to the 5' non-coding sequence. J. Gen. Virol. 78: 2587-2590.

69. Wang, L., Witherington, C., King, A., Gerlach, W.L., Carr, A., Penny, R., Cooper, D., Symonds, G., and Sun, L.-Q. 1998. Preclinical characterization of an anti-tat ribozyme for therapeutic application. Human Gene Ther. 9: 1283-1291.

70. Sarver, N., Cantin, E.M., Chang, P.S., Zaia, J.A., Ladne, P.A., Stephens, D.A., and Rossi, J.J. 1990. Ribozymes as potential antiHIV-1 therapeutic agents. Science. 247: 1222-1225.

71. Leavitt, M.C., Yu, M., Yamada, O., Kraus, G., Looney, D., Poeschla, E., and Wong-Staal, F. 1994. Transfer of an anti-HIV-1 ribozyme gene into primary human lymphocytes. Human Gene Ther. 5: 1115-1120.

72. Yu, M., Leavitt, M.C., Maruyama, M., Yamada, O. Young, D., Ho, A.D., and Wong-Staal, F. 1995. Intracellular immunization of human fetal cord blood stem/progenitor cells with a ribozyme against human immunodeficiency virus type 1. Proc. Natl. Acad. Sci. USA. 92: 699703.

73. Yu, M. Poeschla, E., Yamada, O., Degrandis, P., Leavitt, M.C., Heusch, M., Yees, J-K., Wong-Staal, F., and Hampel, A. 1995. In vitro and in vivo characterization of a second functional hairpin ribozyme against HIV-1. Virol. 206: 381-386.

74. Jolly, D. 1994. Viral vector systems for gene therapy. Cancer Gene Ther. 1: 51-64.

75. Miller, A.D., and Rosman, G.J. 1989. Improved vectors for gene transfer and expression. BioTechniques. 7: 980-986.

76. Verma, I.M., and Somia, N. 1997. Gene Therapy - promises, problems and prospects. Nature. 389: 239-442.

77. Anderson, W.F. 1998. Human gene therapy. Nature. 392 (supp.), 2530.

78. Kavanaugh, M.P., Miller, D.G., Zhang, W., Law, W., Kozak, S.L., Kabat, D., and Miller, A.D. 1994. Cell-surface receptors for gibbon ape leukemia virus and amphotropic retrovirus are inducible sodiumdependent phosphate symporters. Proc. Natl. Acad. Sci. USA. 91: 7071-7075.

79. Bums, J.C., Friedmann, T., Driever, W., Burrascano, M., and Yee, J.K. 1993. Vesicular stomatititis virus G glycoprotein pseudotyped retroviral vectors: concentration to very high titer and efficient gene transfer into nonmammalian cells. Proc. Natl. Acad. Sci. USA. 90: 8033-8037.

80. Von kalle, C., Kiem, H.P., Goehle, So, Darovsky, B., Heimfeld, S., Torokstorb, B., Storb, R., and Schuening, F.G. 1994. Increased gene transfer into human haematopoietic progenitor cells by extended in vitro exposure to pseudotyped retroviral vector. Blood. 84: 2890-2897.

81. Knop A.E., Arndt, A., Raponi, M., Boyd, M.P., Ely, J.A., and Symonds, G. 1999. Artificial capillary culture: Expansion and retroviral transduction of CD4+ T-lymphocytes for clinical application. Gene Therapy. 6: 373-384

82. Kuzcyzka, N. 1992. Use of adeno-associated virus as a general transduction vector in mammalian cells. Curr. Top. Microbiol. Imuunol. 158: 97-129.

83. Chatterjee, S., Johnson, P.R., and Wong, Jr., K.K. 1992. Dual-target inhibition of HIV-1 in vitro by means of an adeno-associated virus antisense vector. Science. 258: 1485-1488.

84. Carter, D.J. 1992. Adeno-associated virus vectors. Curr. Opin. Biotechnol. 3: 533-539.

85. Malik, P., McQuiston, S.A., Yu, X.J., Pepper, K.A., Krall, W.J., Podsakoff, G.M., Kurtzmann, G.J., and Kohn, D.B. 1997. Recombinant adeno-associated virus mediates a high level of gene transfer but less efficient integration in the K562 human hematopoietic cell line. J. Virol. 713., 1776-1783.

86. Lever A.M.L. 1996. HIV and other lentivirus-based vectors. Gene Therapy. 3: 470-471.

87. Naldini, L., Blomer, U., Gallay, P., Mulligan, R., Gage, F.H., Verma, I.M., and Trono, D. 1996. In vivo gene delivery and stable transduction of nondividing cells by a lentiviral vector. Science. 272: 263-267.
88. Quinn, E.R., Lum, L.G., and Trevor, K.T. 1998. T cell activation modulates retrovirus-mediated gene expression. Human Gene Ther. 9: 1457-1467.

89. Rossi, J.J. and Couture, L.A. 1999. Intracellular Ribozyme Applications: Principles and Protocols. Horizon Scientific Press, Wymondham, UK. 


\section{Further Reading}

Caister Academic Press is a leading academic publisher of advanced texts in microbiology, molecular biology and medical research. Full details of all our publications at caister.com

- MALDI-TOF Mass Spectrometry in Microbiology Edited by: M Kostrzewa, S Schubert (2016) www.caister.com/malditof

- Aspergillus and Penicillium in the Post-genomic Era Edited by: RP Vries, IB Gelber, MR Andersen (2016) www.caister.com/aspergillus2

- The Bacteriocins: Current Knowledge and Future Prospects Edited by: RL Dorit, SM Roy, MA Riley (2016)

www.caister.com/bacteriocins

- Omics in Plant Disease Resistance Edited by: V Bhadauria (2016) www.caister.com/opd

- Acidophiles: Life in Extremely Acidic Environments Edited by: R Quatrini, DB Johnson (2016) www.caister.com/acidophiles

- Climate Change and Microbial Ecology: Current Research and Future Trend

Edited by: J Marxsen (2016)

www.caister.com/climate

- Biofilms in Bioremediation: Current Research and Emerging Technologies

Edited by: G Lear (2016)

www.caister.com/biorem

- Microalgae: Current Research and Applications Edited by: MN Tsaloglou (2016) www.caister.com/microalgae

- Gas Plasma Sterilization in Microbiology: Theory, Applications, Pitfalls and New Perspectives Edited by: H Shintani, A Sakudo (2016) www.caister.com/gasplasma

- Virus Evolution: Current Research and Future Directions Edited by: SC Weaver, M Denison, M Roossinck, et al. (2016) www.caister.com/virusevol

- Arboviruses: Molecular Biology, Evolution and Control Edited by: N Vasilakis, DJ Gubler (2016) www.caister.com/arbo

- Shigella: Molecular and Cellular Biology Edited by: WD Picking, WL Picking (2016) www.caister.com/shigella

-Aquatic Biofilms: Ecology, Water Quality and Wastewater Treatment

Edited by: AM Romaní, H Guasch, MD Balaguer (2016)

www.caister.com/aquaticbiofilms

- Alphaviruses: Current Biology

Edited by: S Mahalingam, L Herrero, B Herring (2016)

www.caister.com/alpha

- Thermophilic Microorganisms

Edited by: F Li (2015)

www.caister.com/thermophile
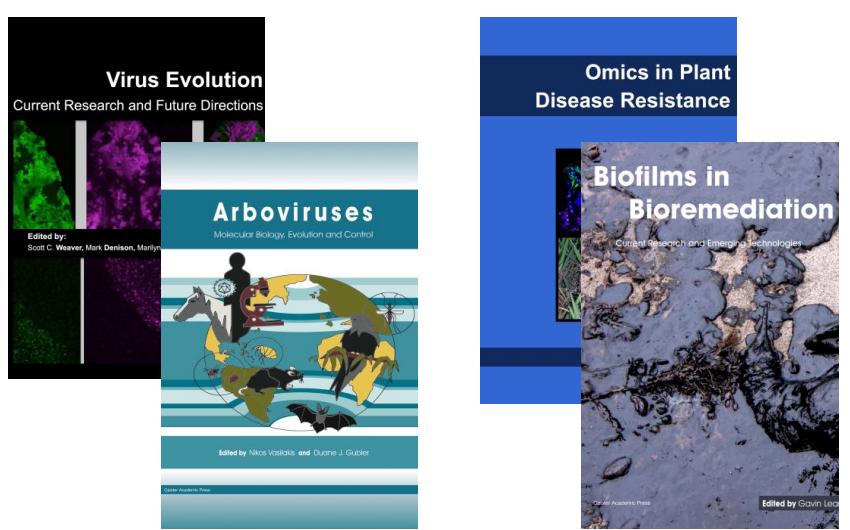
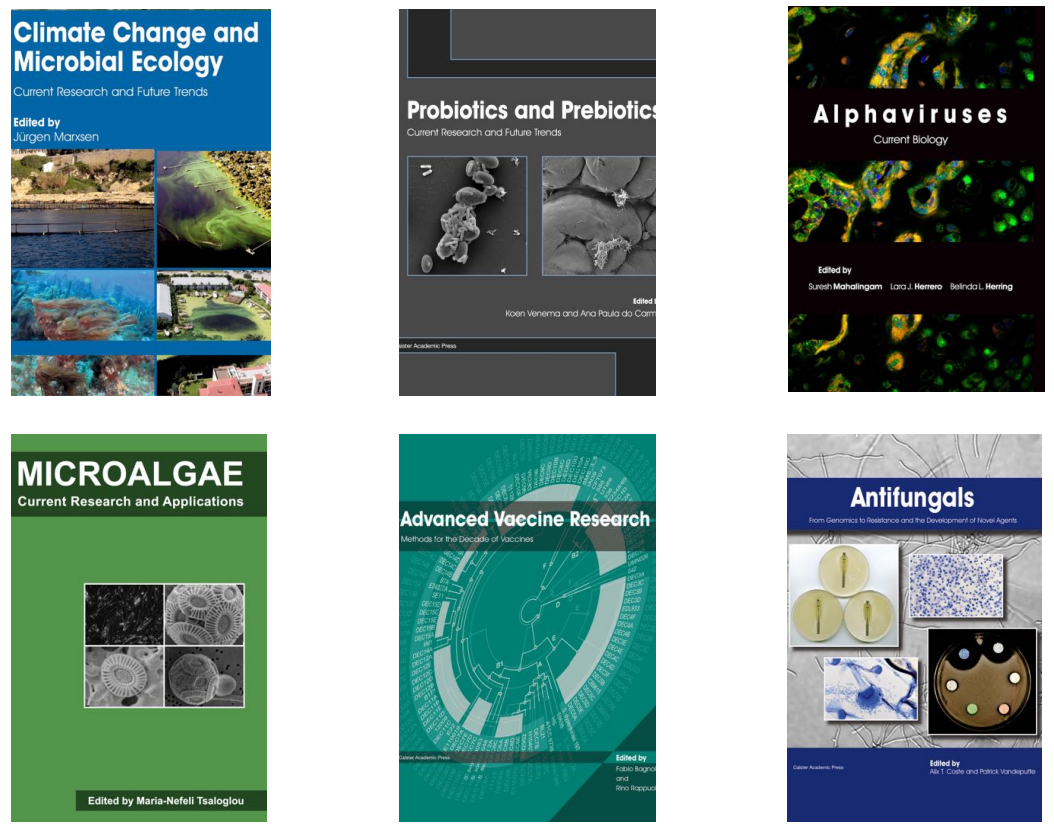

- Flow Cytometry in Microbiology: Technology and Applications Edited by: MG Wilkinson (2015) www.caister.com/flow

- Probiotics and Prebiotics: Current Research and Future Trends Edited by: K Venema, AP Carmo (2015) www.caister.com/probiotics

- Epigenetics: Current Research and Emerging Trends Edited by: BP Chadwick (2015) www.caister.com/epigenetics2015

- Corynebacterium glutamicum: From Systems Biology to Biotechnological Applications

Edited by: A Burkovski (2015)

www.caister.com/cory2

- Advanced Vaccine Research Methods for the Decade of Vaccines

Edited by: F Bagnoli, R Rappuoli (2015)

www.caister.com/vaccines

- Antifungals: From Genomics to Resistance and the Development of Novel Agents

Edited by: AT Coste, P Vandeputte (2015)

www.caister.com/antifungals

- Bacteria-Plant Interactions: Advanced Research and Future Trends Edited by: J Murillo, BA Vinatzer, RW Jackson, et al. (2015) www.caister.com/bacteria-plant

\section{- Aeromonas}

Edited by: J Graf (2015)

www.caister.com/aeromonas

- Antibiotics: Current Innovations and Future Trends

Edited by: S Sánchez, AL Demain (2015)

www.caister.com/antibiotics

- Leishmania: Current Biology and Contro Edited by: S Adak, R Datta (2015) www.caister.com/leish2

- Acanthamoeba: Biology and Pathogenesis (2nd edition) Author: NA Khan (2015)

www.caister.com/acanthamoeba2

- Microarrays: Current Technology, Innovations and Applications Edited by: Z He (2014)

www.caister.com/microarrays2

- Metagenomics of the Microbial Nitrogen Cycle: Theory, Methods and Applications

Edited by: D Marco (2014)

www.caister.com/n2 